\title{
TEMPORAL AND SPATIAL PATTERNS OF SPECIFIC LEAF WEIGHT IN SUCCESSIONAL NORTHERN HARDWOOD TREE SPECIES ${ }^{1}$
}

\author{
THOMAS W. JURIK ${ }^{2}$ \\ University of Michigan Biological Station, Ann Arbor, Michigan 48109-1048
}

\begin{abstract}
A B S T R A C T
Temporal and spatial patterns of specific leaf weight (SLW, $\mathrm{g} / \mathrm{m}^{2}$ ) were determined for deciduous hardwood tree species in natural habitats in northern lower Michigan to evaluate the utility of SLW as an index of leaf photosynthetic capacity. No significant diurnal changes in SLW were found. Specific leaf weight decreased and then increased during leaf expansion in the spring. Most species, especially those located in the understory, then had relatively constant SLW for most of the growing season, followed by a decline in SLW during autumn. Specific leaf weight decreased exponentially down through the canopy with increasing cumulative leaf area index. Red oak (Quercus rubra), paper birch (Betula papyrifera), bigtooth aspen (Populus grandidentata), red maple (Acer rubrum), sugar maple (A. saccharum), and beech (Fagus grandifolia) generally had successively lower SLW, for leaves at any one level in the canopy. On a given site, comparisons between years and comparisons of leaves growing within $35 \mathrm{~cm}$ of each other showed that differences in SLW among species were not due solely to microenvironmental effects on SLW. Bigtooth aspen, red oak, and red maple on lower-fertility sites had lower SLW than the same species on higher-fertility sites. Maximum $\mathrm{CO}_{2}$ exchange rate, measured at lightsaturation in ambient $\mathrm{CO}_{2}$ and leaf temperatures of 20 to $25 \mathrm{C}$, increased with SLW. Photosynthetic capacities of species ranked by SLW in a shaded habitat suggest that red oak, red maple, sugar maple, and beech are successively better adapted to shady conditions.
\end{abstract}

LEAVES ARE KNOWN to be highly plastic in response to their growth conditions, i.e., they can exhibit wide ranges of blade morphology, mesophyll development, and physiological characteristics. Knowledge of how leaf characteristics vary over time and space is required for investigations ranging from studies of intracellular components up to studies of wholecanopy photosynthesis. For such larger scale studies dealing with canopies, it is generally impractical to do extensive measurements of leaf physiological characteristics, since such measurements are usually difficult and timeconsuming. For such reasons, a simple, indirect index of leaf physiological characteristics would be a useful tool for studies dealing with large numbers of leaves.

One possible index is Specific Leaf Weight (SLW), the ratio of blade mass to blade area, which is in general an indicator of leaf thickness and the degree of mesophyll development within a leaf blade. The extent of mesophyll development largely determines the photosynthetic capacity of a leaf (Nobel, Zaragoza and

${ }^{1}$ Received for publication 30 August 1985 ; revision accepted 20 November 1985.

I thank J. Axelrod, B. Gaynor, K. Kandt, J. Simons, A. Parman, and D. Kirschtel for assistance with the field work and D. M. Gates and J. A. Weber for providing the opportunity for this research.

2 Present address: Dept. of Botany, Iowa State University, Ames, IA 50011.
Smith, 1975; Nobel, 1977; Chabot and Chabot, 1977; Chabot, Jurik and Chabot, 1979; Jurik, Chabot and Chabot, 1982), although intracellular effects of other factors such as nutrient supply also influence photosynthetic capacity. Thus, SLW can potentially be used as an indirect measure of the photosynthetic characteristics of a leaf, while also giving a direct measurement of allocations of biomass in a plant. The study of SLW provides a means of integrating various factors such as canopy structure, leaf area index, light environment, and leaf photosynthetic performance. For these reasons, the determination of patterns of SLW within and among plants and over space and time is very useful to studies of the carbon balance and growth of plants, as well as to studies of basic adaptive processes.

This study evaluated temporal and spatial variability in SLW of several major tree species of northern hardwood successional forests. Specific Leaf Weight was related to photosynthetic capacity to determine if SLW can be used as an index of physiological characteristics and to determine if species can be differentiated on the basis of their photosynthetic characteristics.

MeThodS-Field sites were located at the Univ. of Michigan Biological Station near Pellston, Michigan $\left(45^{\circ} 33^{\prime} \mathrm{N}, 84^{\circ} 42^{\prime} \mathrm{W}\right)$. The 
original forest was completely removed by logging and burning by 1909 . Some of the successional regrowth forests on the sites have since been subjected to cutting or burning. Two 1-ha plots on soils of relatively high and low soil fertility (see Koerper and Richardson, 1980) were clearcut in 1972 (the "HIFE" and "LOFE" sites, respectively). Regrowth has been rapid on HIFE, with trees reaching six to ten $m$ height by 1984; a dense, diverse understory has developed. Regrowth on LOFE has been relatively slow, with most trees only three to six $m$ in height by 1984 ; there was only a sparse understory. One hundred $\mathrm{m}$ southeast of LOFE was a site burned in 1954 ("54 BURN"), one of a series of planned burns designed to study successional trends. Canopy trees were six to nine $\mathrm{m}$ tall in 1984. The Upper Grapevine (UPGR) site supported a successional forest 60 to 70 years of age. Average ht of trees in the overstory was approximately $15 \mathrm{~m}$. The Grapevine Trail (GRTR) site was $80 \mathrm{~m}$ east of the UPGR site and had a canopy similar to that at UPGR. In 1984, bigtooth aspen (Populus grandidentata Michx.) dominated the canopy at all sites. Red maple (Acer rubrum L.) and red oak (Quercus rubra L.) were also important canopy species, with their abundances varying somewhat among sites. Paper birch (Betula papyrifera Marsh.) and trembling aspen (Populus tremuloides Michx.) were occasionally present on some of the sites. The GRTR site supported a greater number of species, especially in the understory, than did the other sites. At GRTR, sugar maple (Acer saccharum Marsh.) and red oak were the most common woody understory species, with beech (Fagus grandifolia Ehrh.), striped maple (Acer pennsylvanicum $\mathrm{L}$.), basswood (Tilia americana $\mathrm{L}$.), shadbush (Amelanchier sp.), and several other species also present.

All deciduous tree species on the study sites produced only a single set of leaves, during a relatively short period in late spring. Aspen has an indeterminate pattern of leaf production on many sites over its entire range of habitats. Although young aspen sprouts on recently cleared areas at the Biological Station may exhibit continuous production of leaves throughout the summer, older aspen stems produce only a single set of leaves, possibly because of the relatively low fertility of the soils in this region. This study thus dealt with leaves all produced in late spring and all dying in autumn. Leaf expansion of all species except bigtooth aspen typically was completed before June, whereas bigtooth aspen leaf expansion often was not completed until the second or third week of June.
Leaves for determination of seasonal patterns of SLW were usually collected in late morning; the interval between sample dates varied from one to four wks. For a study of diurnal patterns of SLW, five leaves of each species were collected for each of five sample times spaced at three-hr intervals from 6:30 to 18:30 local solar time on 30 August 1984. Time of day for collection of samples in other studies varied. Leaf areas were measured with a LICOR Model 3000 leaf area m; leaf dry mass was determined after drying to constant wt in an oven at $70 \mathrm{C}$.

Leaf Area Index (LAI) was determined for the HIFE, LOFE, and 54 BURN sites by direct harvests (see Jurik, Briggs and Gates, 1985). Three $1.5 \mathrm{~m} \times 1.5 \mathrm{~m}$ plots on each site were harvested by sequentially erecting sections of scaffolding and collecting all leaves of arborescent, woody species in each $0.5 \mathrm{~m}$ or $1.0 \mathrm{~m}$ ht increment. For each species, leaf area (of one side of the leaf) and dry mass were determined for 50 leaves (lumped) from each canopy level; total leaf area of each species in each level was calculated from the total dry leaf mass and the mass/area ratio (i.e., the SLW) determined from the 50-leaf sample. For comparison, SLW was also individually determined on five leaves from each canopy level. Harvest plots were arbitrarily located in areas of "uniform" canopy, except for the LOFE-3 plot, which was near a dense clump of red maple sprouts in a clone of bigtooth aspen. The plots were harvested during the last week of August 1984 and the first two weeks of September 1984 , before any leaffall occurred.

Gas exchange of single, attached leaves was monitored using a mobile laboratory at the UPGR and GRTR field sites. Leaves from 0.5 to $1.5 \mathrm{~m}$ above ground, on seedlings and small saplings, were sampled at GRTR. At UPGR, a tower made of scaffolding material allowed use of leaves growing in the upper part of the canopy. The gas exchange measurement system was an open-circulation system with an infrared $\mathrm{CO}_{2}$ gas analyzer, as described in $\mathrm{Ju}$ rik, Weber and Gates (1984). Measurements were made in ambient $\mathrm{CO}_{2}$ and $\mathrm{O}_{2}$ levels with saturating light on mature leaves during the period late June to early September during 1981-1983. Data are largely from experimental runs, made at all times of day, in which light and temperature were controlled; some data from daily-time courses of gas exchange, in ambient light and temperature, are also included. Measurements of temperature response of light-saturated $\mathrm{CO}_{2}$ exchange rate (CER) suggested that the optimal temperature for all species was between 20 and $25 \mathrm{C}$, with 


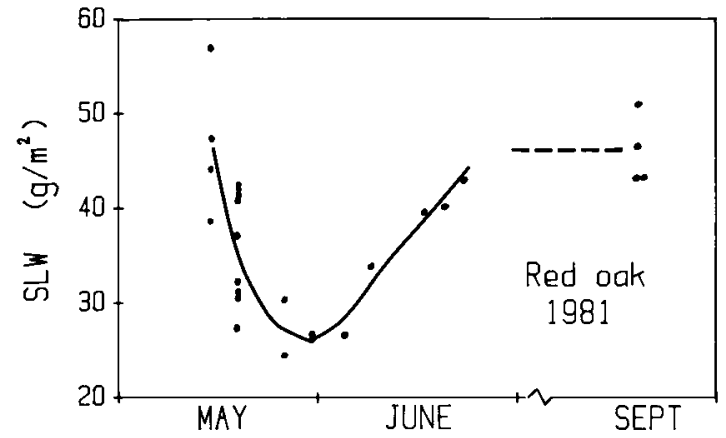

Fig. 1. Changes in Specific Leaf Weight (SLW) of red oak leaves in the understory at Grapevine Trail during and immediately after leaf expansion. Leaf expansion was completed in the first week of June. Each datum is for a different leaf.

little or no change in temperature optimum during the growing season (Jurik, unpubl. data). Data presented here for CER were from measurements between 20 and $25 \mathrm{C}$.

RESULTS-A study of daily variation in SLW of leaves at the top of the UPGR forest canopy on 30 August 1984, a sunny, mild day, showed that red oak had a larger range of mean values $\left(84-98 \mathrm{~g} / \mathrm{m}^{2}\right)$ than either bigtooth aspen (76$\left.85 \mathrm{~g} / \mathrm{m}^{2}\right)$ or paper birch $\left(90-95 \mathrm{~g} / \mathrm{m}^{2}\right)$. In all three species, the highest values of SLW occurred in the afternoon, but the variation among leaves at any one time of day was large enough that there were no statistically significant differences among the mean values for any one species (Student-Newman-Keuls multiple range test, $P>0.05$ ). Leaves in the understory were not studied because experience showed that variability in sampling was as large as the probable maximum diurnal effects, as judged from the samples at the top of the canopy.

Specific Leaf Weight changed greatly during and just after leaf expansion, as illustrated in Fig. 1 for red oak in the understory. Specific Leaf Weight declined from leaf appearance until near the completion of leaf expansion in the first week of June. SLW then increased for several wk after expansion had ceased.

After the initial changes in SLW attributable to leaf growth and maturation, SLW varied relatively little over most of the growing season (Fig. 2, 3). Each datum is the mean of three to five leaves. Leaves growing in full sun and in the understory at the UPGR site had relatively little change in SLW from June to mid-September (Fig. 2). (Sampling of these leaves started near the completion of leaf expansion and hence does not show the early changes in SLW during leaf expansion.) For most species, there

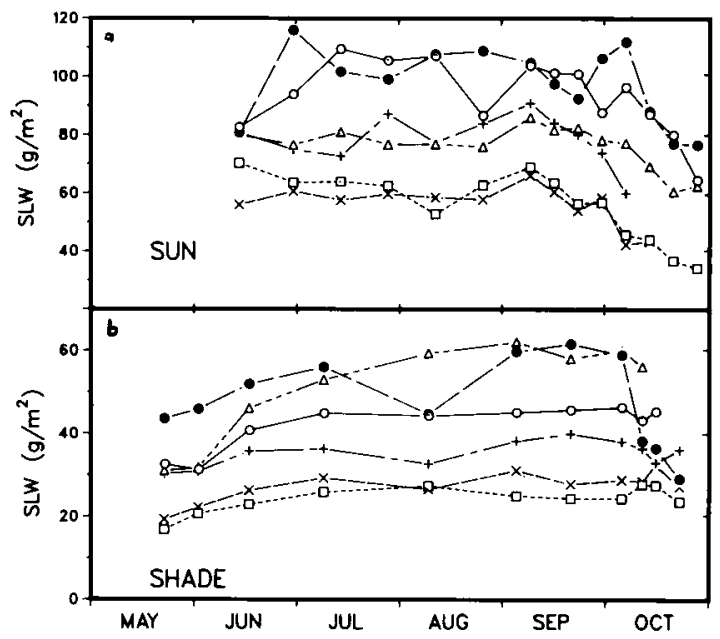

Fig. 2. Seasonal patterns of Specific Leaf Weight (SLW) of leaves at Upper Grapevine. a) Leaves growing in full sun at the top of the canopy or, for sugar maple and beech, on isolated trees in clearings. b) Leaves growing in shade in the understory or, for paper birch and bigtooth aspen, at the lowest point they existed in the canopy. Key: $O$ red oak, $\triangle$ paper birch, $\Delta$ bigtooth aspen, + red maple, $\square$ beech, $\times$ sugar maple.

was a decline in SLW during leaf senescence in late September and October. The "SHADE" leaves of bigtooth aspen and paper birch were from the lowermost branches of canopy trees, since these species were not present in the understory; these leaves thus may have been in slightly higher light than the other species. For sun-grown leaves, red oak and paper birch had the highest SLW; sugar maple and beech had the lowest SLW, while bigtooth aspen and red maple were intermediate (Fig. 2a). For shade-grown leaves, paper birch and bigtooth aspen had the highest SLW; sugar maple and beech again had the lowest SLW, while red oak and red maple were intermediate (Fig. 2b). The species thus can adjust their leaf anatomy, and hence SLW, to different growth light levels. The species also appear to maintain approximately the same relative ranking in regard to the response of SLW to light in both sun and shade.

Seasonal patterns of SLW for seven understory species at GRTR were very similar in 1980 and 1981 (Fig. 3). The species expanded their leaves at different times, so the initial decrease in SLW due to leaf expansion (see Fig. 1) was not seen consistently in 1980, when sampling was not begun as early as in 1981 . Red maple, round-leaf dogwood (Cornus rugosa Lam.), and Maianthemum canadense Desf., a perennial herb, consistently had higher SLW than beech, sugar maple, striped maple, and maple-leaf viburnum (Viburnum acerifol- 


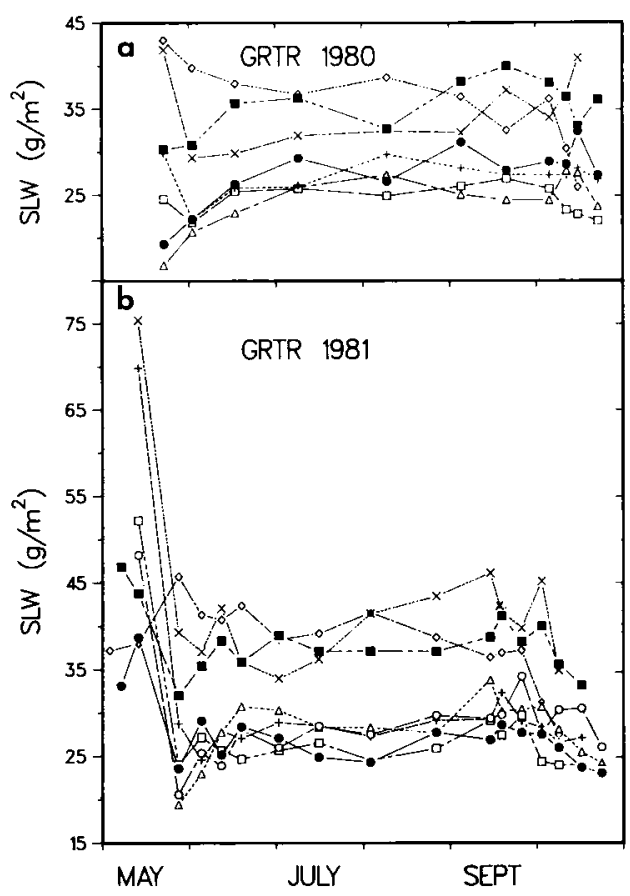

Fig. 3. Seasonal patterns of Specific Leaf Weight (SLW) of leaves in the understory at Grapevine Trail. a) 1980, b) 1981. Key: - sugar maple (seedlings), $O$ sugar maple (small saplings), $\square$ striped maple, $\square$ red maple, $\Delta$ beech, + maple-leaf viburnum, $\times$ round-leaf dogwood, $\diamond$ Maianthemum canadense.

ium L.). All species had relatively constant SLW from mid-June to mid-September, after which SLW generally declined during leaf senescence.

The above ranking of understory species by SLW incorporates variability in microenvironment as well as variation over time. Larger scale variation in habitats could also affect such comparisons; for example, the values shown in Fig. 2 for red oak in the understory were from a location about $100 \mathrm{~m}$ from the site where the data of Fig. 3, for other species, were collected. Does red oak really have higher SLW than most other understory species, or was it by chance or necessity growing in an area with more light? To eliminate the effect of microenvironment, pairs or triplets of leaves growing within $35 \mathrm{~cm}$ of each other at GRTR were compared. Figure 4 shows the mean difference in SLW between any two species, based on the differences in SLW of several sets of paired leaves. Red oak consistently had the highest SLW, while white ash (Fraxinus americana L.) had the lowest. The direction of differences was consistent among all species combinations, and the "distance" among species (i.e., the difference in SLW) was remarkably consistent when measured via direct versus indirect comparisons. For example, the distance from red oak to beech was 15; the sum of the red oak-sugar
Higher S LW

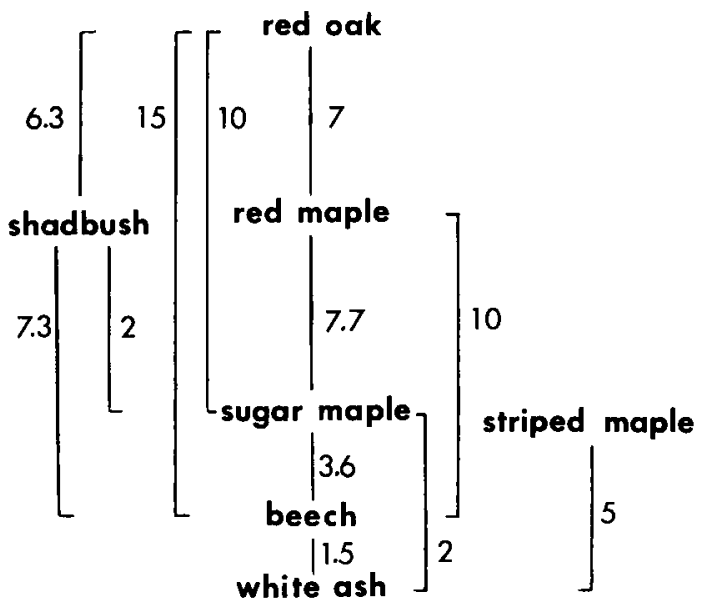

Lower SLW

Fig. 4. Relative ranking of species according to Specific Leaf Weight (SLW). The "distance" between species is the mean difference in SLW $\left(\mathrm{g} / \mathrm{m}^{2}\right)$ of leaves growing in the same microenvironment (i.e., within $35 \mathrm{~cm}$ of each other).

maple (10) and sugar maple-beech (3.6) distances was 13.6 (Fig. 4).

The harvest plots at the HIFE, LOFE, and 54 BURN sites revealed patterns of leaf characteristics through the canopy. Mean SLW of the individual samples was an excellent predictor of the "true" SLW measured by the 50leaf samples. For all species and sites combined, there was very nearly a $1: 1$ relationship between the individual means $\left(S_{L} W_{\text {ind }}\right)$ and the bulk samples (SLW bulk $_{\text {, }}$, as indicated by the regression equation $\mathrm{SLW}_{\text {bulk }}=2.70+$ $0.962 * \mathrm{SLW}_{\text {ind }}(N=91$; slope $>0, P<0.01$; $r^{2}=0.93$ ). For individual species and plots, only four of 20 regressions of the 50-leaf samples versus the individual leaf means were nonsignificant, and these either were based on very few samples $(N<5)$ or had a very limited range of values of SLW. These results suggest that individual determination of SLW of five or more leaves is probably sufficient to give a reasonable picture of differences in SLW at different levels in a canopy.

The average and range of the coefficient of variation (standard deviation divided by the mean, in percent) for the several canopy levels in each harvest plot, based on the five individual determinations of SLW for each level in the canopy, were similar among species. Over all plots, the mean, range, and number of samples were: bigtooth aspen, 8.1, 2.7-19.5, 49; red oak, 8.6, 3.8-18.3, 19; red maple, 10.3, 3.8-24.4, 24; all (five) species combined, 8.8, $2.7-24.4,100$. There were no apparent trends with position in the canopy (data not shown), 

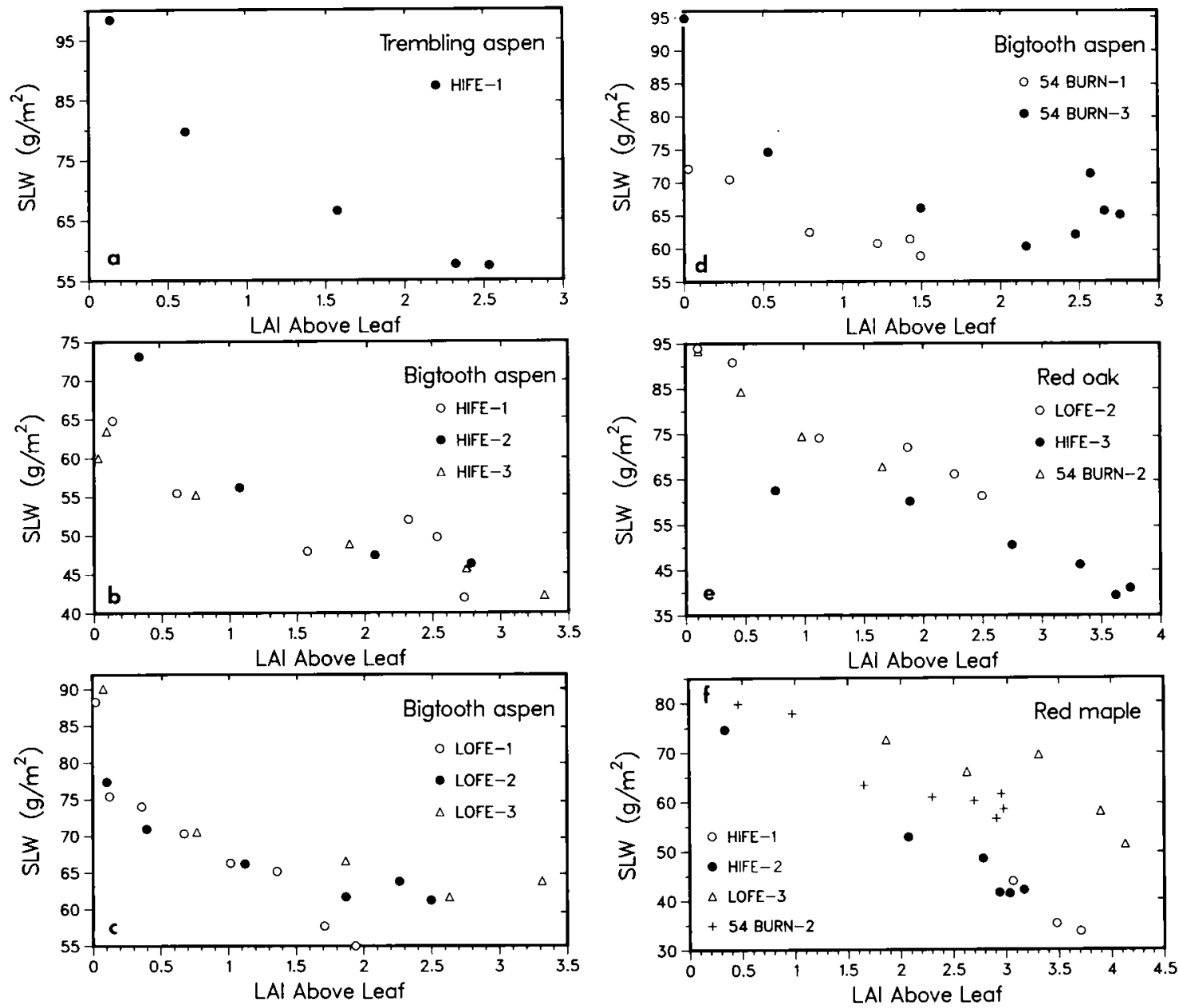

Fig. 5. Specific Leaf Weight (SLW) of leaves in each harvest interval versus total LAI above the midpoint of the harvest interval, by species and site. Mean SLW was determined from the total area and total dry mass of 50 leaves. a) Trembling aspen (HIFE), b) bigtooth aspen (HIFE), c) bigtooth aspen (LOFE), d) bigtooth aspen (54 BURN), e) red oak, f) red maple.

indicating that there is about the same relative degree of variation in SLW of leaves throughout the canopy.

In Fig. 5, SLW is plotted as a function of total LAI above the midpoint of each harvest interval. Specific Leaf Weight declined with increasing cumulative LAI, for all species and sites. Regressions of SLW against the reciprocal of the exponential of LAI ("EXP" model), with $k=1.0$ (the extinction coefficient), were statistically significant for almost all of the samples (Table 1). Regressions using the EXP model with $\mathrm{k}=0.732$, an extinction coefficient for light found in deciduous forests in Tennessee by Baldocchi et al. (1984), gave essentially the same results (data not shown). Regressions using the EXP model and combining data from all harvest plots on a site typically had goodness-of-fits $\left(r^{2}\right)$ lower than those of regressions for single plots, although the combined plot regressions were all statistically highly significant (Table 1). Regressions using the log of SLW versus LAI gave slightly better fits than the EXP model for red maple and red oak at HIFE, but were otherwise worse (data not shown). Similarly, a linear model of SLW versus LAI gave the best fits for red maple and for red oak at HIFE but gave poorer fits than the EXP model in the other cases. At HIFE, red oak and red maple were limited to the lower part of the canopy, so that a full range of light environments and potential SLWs was not present; the lower portion of an exponential curve could easily be perceived as linear, in such cases.

Higher soil fertility resulted in lower SLW, for any given cumulative LAI (Fig. 5; Table 1). Bigtooth aspen on the LOFE and 54 BURN (lower-fertility) sites had SLW about $15 \mathrm{~g} / \mathrm{m}^{2}$ higher than bigtooth aspen on the HIFE (higher- 

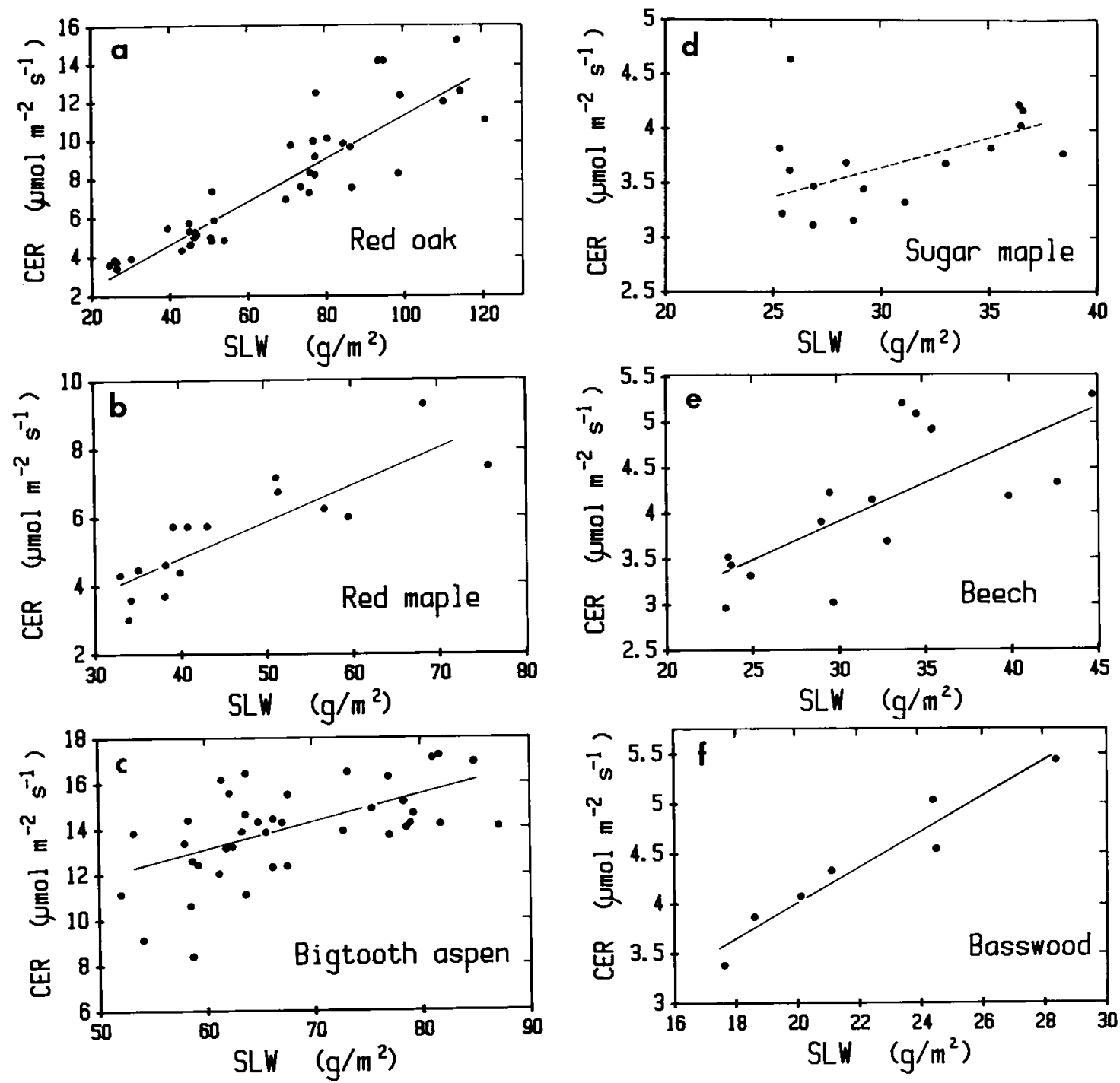

Fig. 6. $\mathrm{CO}_{2}$ Exchange Rate (CER) versus Specific Leaf Weight (SLW) of leaves at the Upper Grapevine and Grapevine Trail sites. CER was measured at light-saturation, optimum temperature (20-25 C), and ambient $\mathrm{CO}_{2}$; each datum is a measurement on a different leaf. Data are from 1981,1982, and 1983. The lines are linear regressions of CER versus SLW (see Table 2). a) Red oak, b) red maple, c) bigtooth aspen, d) sugar maple, e) beech, f) basswood.

fertility) site; red maple and red oak were 5 and $9 \mathrm{~g} / \mathrm{m}^{2}$ higher, respectively, on the LOFE and 54 BURN sites than on the HIFE site. For any given cumulative LAI at HIFE, bigtooth aspen, red maple, red oak, and trembling aspen had successively higher SLW. At the lowerfertility sites, the species had the same relative order (with no trembling aspen present), although absolute values of SLW differed.

Maximum, light-saturated $\mathrm{CO}_{2}$ exchange rate (CER) at optimum temperature in ambient $\mathrm{CO}_{2}$ generally increased with SLW (Fig. 6). Data are all from the UPGR and GRTR sites, with similar soil fertility. Due to the successional nature of the forest, sugar maple, beech, and basswood were only rarely represented at the top of the canopy and hence there are no high-SLW samples for these species. Bigtooth aspen was apparently limited by its intolerance of shade and did not produce SLWs lower than $50 \mathrm{~g} / \mathrm{m}^{2}$ on these sites. Regressions of CER on SLW, using a linear model, had highly statistically significant positive slopes for all species but sugar maple (Table 2). Red oak had the widest range of SLW and CER and clearly exhibited a linear relationship of CER to SLW (Fig. 6a). Red maple (Fig. 6b) had a pattern very similar to that of red oak, although the range of SLW was more limited. Bigtooth aspen had some increase in CER with SLW, although CER seemed 
TABLE 1. Regressions of Specific Leaf Weight $\left(\mathrm{g} / \mathrm{m}^{2}\right) \mathrm{ver}$ sus cumulative Leaf Area Index (LAI) above a given level on the harvest plots. The regression equation was. $S L W=a+b^{*} \operatorname{Exp}\left(-k^{*} L A I\right)$, with $k=1.0$. The significance column is for the test of $b=0\left(^{*}, P<0.05\right.$; **, $P<0.01 ; n s, P>0.05$ )

\begin{tabular}{lccccc}
\hline \hline Species/site & $a$ & $b$ & $n$ & $\begin{array}{c}\text { Sig- } \\
\text { nif }\end{array}$ & $r^{2}$ \\
\hline Bigtooth aspen & & & & & \\
HIFE-1 & 45.414 & 21.217 & 6 & $*$ & 0.81 \\
HIFE-2 & 42.767 & 41.843 & 4 & $* *$ & 0.99 \\
HIFE-3 & 44.316 & 19.073 & 6 & $* *$ & 0.93 \\
LOFE-1 & 53.355 & 31.238 & 8 & $* *$ & 0.90 \\
LOFE-2 & 60.117 & 18.073 & 6 & $* *$ & 0.96 \\
LOFE-3 & 60.660 & 29.937 & 5 & $* *$ & 0.95 \\
54 BURN-1 & 55.746 & 17.553 & 6 & $* *$ & 0.95 \\
54 BURN-3 & 61.638 & 30.125 & 8 & $* *$ & 0.85 \\
HIFE 1-3 & 45.22 & 22.269 & 16 & $* *$ & 0.76 \\
LOFE 1-3 & 58.241 & 25.246 & 19 & $* *$ & 0.81 \\
54 BURN 1, 3 & 60.25 & 19.868 & 14 & $* *$ & 0.51 \\
Red oak & & & & & \\
HIFE-3 & 44.113 & 45.332 & 6 & $*$ & 0.66 \\
LOFE-2 & 62.269 & 37.838 & 6 & $* *$ & 0.95 \\
54 BURN-2 & 60.898 & 36.402 & 4 & $* *$ & 0.99 \\
Red maple & & & & & \\
HIFE-1 & 21.392 & 476.48 & 3 & ns & 0.98 \\
HIFE-2 & 42.333 & 47.936 & 7 & $* *$ & 0.93 \\
LOFE-3 & 56.659 & 113.42 & 5 & ns & 0.56 \\
54 BURN-2 & 57.102 & 40.469 & 8 & $* *$ & 0.90 \\
HIFE 1-2 & 39.651 & 53.19 & 10 & $* *$ & 0.87 \\
Trembling aspen & & & & & \\
HIFE-1 & 53.726 & 50.653 & 5 & $* *$ & 0.99 \\
\hline
\end{tabular}

to plateau at SLWs above $70 \mathrm{~g} / \mathrm{m}^{2}$ (Fig. 6c). Bigtooth aspen had higher CER for a given SLW than red maple and red oak. Sugar maple and beech in the understory (Fig. 6d, e) had much smaller ranges of SLW than the above species. In beech, CER increased with SLW (Fig. 6e). If one probable outlier for sugar maple (at $26 \mathrm{~g} / \mathrm{m}^{2}$, Fig. 6d) is excluded, sugar maple also shows a statistically significant increase in CER with SLW (Table 2). Differences among and within plants in both long-term effects on CER, such as nutrient supply, and shorter-term effects on CER, such as mid-afternoon water stress, undoubtedly contributed to the variation seen in all species. The data for basswood (Fig. 6f) show that much of the variation is due to such differences among plants. The basswood data are from a single sapling in the understory and hence show the effect of standardizing factors such as nutrient supply and light environment. Although the range of SLW was very limited, there was a very close relationship between CER and SLW (Table 2).

Since it is nearly impossible to find leaves of four or more species growing in the same microenvironment, i.e., within a few $\mathrm{cm}$ of each other, most comparisons of CER of
TABLE 2. Regressions of $\mathrm{CO}_{2}$ Exchange Rate (CER, $\mu \mathrm{mol}$ $\left.m^{-2} s^{-1}\right)$ versus Specific Leaf Weight $\left(S L W, g / m^{2}\right)$ for individual leaves from the UPGR and GRTR sites, measured over the years 1981-1983. The regression equation was: $C E R=a+b^{*} S L W$. The significance column is for the test of $b=0\left(^{*}, P<0.05^{* *}, P<\right.$ $0.01 ; n s, P>0.05$ ). The second equation for sugar maple excludes the datum at $S L W=26 \mathrm{~g} / \mathrm{m}^{2}$

\begin{tabular}{lccccc}
\hline \hline \multicolumn{1}{c}{ Species } & $a$ & $b$ & $n$ & $\begin{array}{c}\text { Sig- } \\
\text { nif. }\end{array}$ & $r^{2}$ \\
\hline Bigtooth aspen & 5.49 & 0.123 & 40 & $* *$ & 0.33 \\
Red maple & 0.44 & 0.109 & 16 & $* *$ & 0.73 \\
Red oak & 0.17 & 0.112 & 40 & $* *$ & 0.81 \\
Beech & 1.45 & 0.081 & 16 & $* *$ & 0.53 \\
Sugar maple & 2.68 & 0.032 & 16 & ns & 0.13 \\
Sugar maple (exc pt) & 2.05 & 0.051 & 15 & $* *$ & 0.46 \\
Basswood & 0.46 & 0.177 & 7 & $* *$ & 0.93 \\
\hline
\end{tabular}

understory leaves incorporate variation due to different growth environments. This variation makes it difficult to rank species by photosynthetic capacity, since one does not know whether a given photosynthetic capacity is due to innate differences among species or due to environmental effects. Species could be growing only in microenvironments that suit their growth requirements; subtle differences among such environments might not be apparent and might not be averaged out over many measurements of different leaves growing in microenvironments that were classified as the same by a human observer. The ranking of species by SLW presented in Fig. 4 and the relationships of CER to SLW presented in Fig. 6 may be combined to reduce much of the uncertainty in ranking species by photosynthetic capacity. For SLW of sugar maple arbitrarily chosen to be $27 \mathrm{~g} / \mathrm{m}^{2}$, SLWs of red oak, red maple, and beech derived from Fig. 4 are 39,27 , and $23 \mathrm{~g} / \mathrm{m}^{2}$, respectively. This represents a hypothetical situation in which all species are growing in the same microenviroment. For each species, photosynthetic capacity (as indicated by light-saturated CER) is calculated from Fig. 6. $\mathrm{CO}_{2}$ exchange rate per unit leaf area is highest in red oak $(4.54 \mu \mathrm{mol}$ $\mathrm{m}^{-2} \mathrm{~s}^{-1}$ ) and successively lower in red maple (4.15), sugar maple (3.43), and beech (3.31). The species exhibit the reverse pattern for CER per unit leaf mass, with beech highest (144 nmol $\mathbf{g}^{-1} \mathbf{s}^{-1}$ ) and sugar maple (127), red maple (122), and red oak (116) successively lower.

DisCUSSION-Temporal changes in SLW of leaves at any point in the canopy can influence interpretations of the relationship between SLW and other leaf characteristics such as photosynthetic rate. Although there was little change in SLW over the course of a day in the tree leaves studied here, the seasonal changes in 
SLW were large and must be considered in comparisons of SLW. The largest changes in SLW occurred during and immediately after leaf expansion. Coyne and Van Cleve (1977) also found a pattern of rapid increase in SLW (of trembling aspen) during early June, followed by a more gradual increase over the summer, although their measurements apparently did not start early enough to show a decline in SLW very early in leaf growth. Similarly, Lewandowska and Jarvis (1977) found SLW of spruce needles to increase gradually over the course of a year. Changes in SLW early in leaf growth are presumably due to changes in relative rates of cell division and cell expansion (Steer, 1971). Decreases in SLW during leaf senescence in autumn are due primarily to retranslocation of sugars and nutrients (Ostman and Weaver, 1982). The relative constancy of SLW from late June to early September found here, especially in understory leaves, reflects both relative constancy of environment and constancy of leaf developmental stage. Since photosynthetic capacity is also constant during this period but varies during leaf expansion and leaf senescence (Jurik, 1986), studies of the relationship of SLW to photosynthetic capacity of leaves will be least confounded by temporal effects if performed in the period late June to early September, as was done here.

Even after temporal changes in SLW have been accounted for, comparisons of SLW among species still must distinguish genetic and environmental effects on SLW. There is undoubtedly a genetic influence on SLW, as shown by comparisons among and within species grown under the same conditions (Barnes et al., 1969; McGee, Schmierbach and Bazzaz, 1981; Ledig and Korbobo, 1983), although the magnitudes of genetic differences in SLW are generally much less than differences due to environmental effects. For a given genotype, SLW can be influenced by a variety of environmental conditions, with leaves being most sensitive to conditions prevailing during leaf expansion (Jurik, Chabot and Chabot, 1979). Leaves in shady environments typically have lower SLW than leaves grown in sunny conditions; lower SLW represents a complement of leaf characteristics including decreased leaf thickness, decreased palisade cell development, decreased RubP carboxylase, increased chlorophyll per unit leaf mass, lower light-saturation point and maximum rate of photosynthesis, decreased respiration rate, and so on (Boardman, 1977; Chabot and Chabot, 1977).

Recent investigations have started to reveal the modes of operation of various environmental factors in determining SLW and pho- tosynthetic capacity. Light primarily appears to influence anatomical development, with higher light levels leading to thicker leaves with greater development of the mesophyll (Nobel et al., 1975; Nobel, 1977; Chabot et al., 1979; Björkman, 1981; Jurik et al., 1982). This greater mesophyll development means greater SLW and, often, higher photosynthesis per unit leaf area due to more photosynthesizing cells per unit leaf area. Leaves apparently integrate the various light levels received over a day and adjust their anatomy in response to the total amount of light received (Nobel, 1976; Chabot et al., 1979). Lower growth temperatures lead to increased SLW in alfalfa (Ku and Hunt, 1973). Nutrient supply has its largest effect on photosynthesis at an intracellular level (Longstreth and Nobel, 1980; Jurik et al., 1982). Decreased nutrient availability often leads to increased SLW, as has been noted in controlled studies of a variety of species (Oxman, Goodman and Cooper, 1977; Longstreth and Nobel, 1980; Jurik et al., 1982), although decreases in SLW have also been found (Yoshida and Coronel, 1976). Low-nutrient leaves often have smaller, more densely packed cells and may accumulate more starch, because photosynthesis outruns the nutrient-limited conversion of photosynthetic products into more complex growth substrates (see Jurik et al., 1982). Leaves on the lower-fertility sites of this study had relatively higher SLW, in accord with many controlled experimental studies, although Coyne and van Cleve (1977) found an increase in SLW with fertilization of aspen stands in the field. Water stress can have direct effects on turgor pressure and hence cell expansion; SLW can be increased by water stress during leaf expansion because decreased cell expansion results in approximately the same mass being spread over a smaller leaf area (see Hsiao, 1973; Smith and Nobel, 1978).

Investigations of spatial variation in SLW within forest canopies typically have found that SLW decreases down through the canopy (Coyne and van Cleve, 1977; Lewandowska and Jarvis, 1977; Schulze, Fuchs and Fuchs, 1977; van Elsacker and Impens, 1984). This trend in SLW apparently occurs in response to light, since other environmental factors have much smaller gradients through the canopy, as do factors within a tree such as nutrient supply and water supply. However, there are surprisingly few simultaneous measurements of SLW and the light environment in the field. Del Rio and Berg (1979) found a negatively linear relationship of SLW to the log of light received at a given point in the canopy. Although no direct measurements of light were made here, the known exponential decline in light with 
increasing LAI (Anderson, 1964; Ross, 1981) and the negative exponential relationship of SLW to cumulative LAI found in this study imply a strong relationship between light and SLW. The similarity of patterns of SLW versus LAI on sites of different fertility also indicates a strong influence of light level on SLW, since absolute values varied somewhat according to site fertility but the exponential decline in SLW with cumulative LAI was the predominant feature of the patterns. Absolute values of SLW for a given LAI and site are also likely to be very dependent on how well the assumption of a uniform canopy (implicit in the exponential equation) is met.

Some investigators have found a positive correlation between SLW and photosynthetic capacity per unit leaf area (e.g., Pearce et al., 1969; Dornhoff and Shibles, 1970, 1976), while others have found no correlation (Ku and Hunt, 1973; see Björkman, 1981). Since environmental and genetic factors may have effects on leaf anatomy and physiological characteristics that are not always translated into proportionate effects on photosynthesis, it is not surprising that a positive relationship between SLW and leaf photosynthetic capacity has not been consistently found, especially in comparisons among species. Species may have more or less dissimilar evolutionary histories that have resulted in particular combinations of leaf anatomy and intracellular photosynthetic capacity, so that different photosynthetic capacities may be achieved by leaves of the same SLW in different species, and vice versa. The species studied here did show fairly clear relationships between SLW and photosynthetic capacity per unit leaf area. The excellent correlation of SLW and photosynthetic capacity found in basswood emphasizes the effects in the other species of genetic variation and variation in environmental factors other than light, since such effects were minimized in the basswood data. The relationships of LAI, light, and SLW suggest that SLW was largely influenced by light and can be predicted from LAI. However, the larger question of why particular levels of photosynthetic capacity versus SLW have evolved in different species cannot yet be answered.

One traditional classification of species is based on their tolerance or intolerance of shade, i.e., their ability to survive and grow underneath a canopy. Species appearing early in a forest successional sequence are typically intolerant of shade, while late-successional or "climax" species are tolerant of shade (Bazzaz, 1979). Can species be ranked by SLW relative to successional status and shade tolerance? The first problem encountered in answering this question is getting a reasonable comparison of
SLW; one must account for as many environmental effects as possible. The consistency of the results of the several different studies here suggests that it is possible to account for much of the environmental variation, so that genetic differences among species can be compared. A second problem is interpreting different SLWs in evolutionary terms; what is the significance of SLW? How does SLW relate to the plant's carbon balance, ability to survive, etc.? Computer simulations of leaf carbon balances have shown that leaves with low-light, tolerant characteristics represented by low SLW do indeed have greater carbon gain per unit investment in leaf material in shady environments than would leaves with high-light characteristics "grown" in shady environments (Jurik, 1980; Jurik and Chabot, 1986); such improvement in carbon gain presumably confers an adaptive advantage. Thus, the ranking of species by SLW in a given environment does give an idea of the relative "adaptedness" of a given species to shade. The comparisons of SLW in this study show that species do indeed have different SLW and photosynthetic capacity for a given microenvironment. Bigtooth aspen, definitely an early successional species, had the highest photosynthetic capacity, even though its highest values of SLW were not as high as those of red oak. Otherwise, SLW was a good indicator of photosynthetic capacity and of relative ability to adapt to shade, with red oak, red maple, sugar maple, and beech having successively lower SLW. This order of species corresponds to that traditionally assigned for successional status and shade tolerance.

\section{LITERATURE CITED}

ANDERSON, M.C. 1964. Light relations of terrestrial plant communities and their measurement. Biol. Rev. 39: 425-486.

Baldocchi, D. D., D. R. Matt, B. A. Hutchison, and R. T. MCMillen. 1984. Solar radiation within an oak-hickory forest: an evaluation of the extinction coefficients for several radiation components during fully-leafed and leafless periods. Agric. For. Meteorol. 32: 307-322.

Barnes, D. K., R. B. Pearce, G. E. Carlson, R. H. Hart, AND C. H. Hanson. 1969. Specific leaf weight differences in alfalfa associated with variety and plant age. Crop Sci. 9: 421-423.

BAZZAZ, F. A. 1979. The physiological ecology of plant succession. Ann. Rev. Ecol. Syst. 10: 351-371.

BJÖRKMAN, O. 1981. Responses to different quantum flux densities. In O. L. Lange, P. S. Nobel, C. B. Osmond, and H. Ziegler [eds.], Physiological plant ecology I: Responses to the physical environment, pp. 57-107. Enc. plant physiology, Vol. 12A. SpringerVerlag, New York. $625 \mathrm{pp}$.

BoARdman, N. K. 1977. Comparative photosynthesis of sun and shade plants. Ann. Rev. Pl. Physiol. 28: 355377.

Chabot, B. F., and J. F. Сhabot. 1977. Effects of light 
and temperature on leaf anatomy and photosynthesis in Fragaria vesca. Oecologia 26: 363-377.

, T. W. JURIK, AND J. F. CHABOT, 1979. Influence of instantaneous and integrated light flux density on leaf anatomy and photosynthesis. Amer. J. Bot. 66: 940-945.

Coyne, P. I., AND K. van Cleve. 1977. Fertilizer induced morphological and chemical responses of a quaking aspen stand in interior Alaska. Forest Sci. 23: 92-102.

Del Rio, E., AND A. Berg. 1979. Specific leaf area of Douglas-fir reproduction as affected by light and needle age. Forest Sci. 25: 183-186.

Dornhoff, G. M., AND R. Shibles. 1970. Varietal differences in net photosynthesis of soybean leaves. Crop Sci. 10: $42-45$.

$\longrightarrow$, AND $\longrightarrow$. 1976. Leaf morphology and anatomy in relation to $\mathrm{CO}_{2}$-exchange rate of soybean leaves. Crop Sci. 16: 377-381.

Hsiao, T. C. 1973. Plant responses to water stress. Ann. Rev. Pl. Physiol. 24: 519-570.

JuRIk, T. W. 1980. Physiology, growth, and life history characteristics of Fragaria virginiana Duchesne and $F$. vesca L. (Rosaceae). Ph.D. dissertation. Cornell University. 439 pp.

- 1986. Seasonal patterns of leaf photosynthetic capacity in successional northern hardwood tree species. Amer. J. Bot. 73: 131-138.

, J. F. CHABOT, AND B. F. CHABOT. 1979. Ontogeny of photosynthetic performance in Fragaria virginiana. Pl. Physiol. 63: 542-547.

,-- AND - 1982. Effects of light and nutrients on leaf size, $\mathrm{CO}_{2}$ exchange, and anatomy in wild strawberry (Fragaria virginiana). Pl. Physiol. 70: 1044-1048.

- J. A. Weber, And D. M. Gates. 1984. Shortterm effects of $\mathrm{CO}_{2}$ on gas exchange of leaves of bigtooth aspen (Populus grandidentata) in the field. P1. Physiol. 75: 1022-1026.

- G. M. Briggs, and D. M. Gates. 1985. A comparison of four methods for determining leaf area index in successional hardwood forests. Can. J. Forest Res. 15: 1154-1158.

—, AND B. F. Chaвot. 1986. Leaf dynamics and profitability in wild strawberries. Oecologia 69: 286304.

KoERPER, G. J., AND C. J. Richardson. 1980. Biomass and net annual primary production regressions for Populus grandidentata on three sites in northern lower Michigan. Can. J. For. Res. 10: 92-101.

KU, S. B., AND L. A. HunT. 1973. Effects of temperature on the morphology and photosynthetic activity of newly matured leaves of alfalfa. Canad. J. Bot. 51: 19071916.

LEDIG, F. T., AND D. R. KORBOBO. 1983. Adaptation of sugar maple populations along altitudinal gradients: photosynthesis, respiration, and specific leaf weight. Amer. J. Bot. 70: 256-265.
LewandowskA, M., AND P. G. JaRvis. 1977. Changes in chlorophyll and carotenoid content, specific leaf area and dry weight fraction in Sitka spruce, in response to shading and season. New Phytol. 79: 247-256.

LoNGSTRETH, D. J., AND P. S. NoBel. 1980. Nutrient influences on leaf photosynthesis: Effects of nitrogen, phosphorus and potassium for Gossypium hirsutum L. P1. Physiol. 65: 541-543.

McGee, A. B., M. R. Schmierbach, ANd F. A. Bazzaz. 1981. Photosynthesis and growth in populations of Populus deltoides from contrasting habitats. Amer. Midl. Natur. 105: 305-311.

Nobel, P. S. 1976. Photosynthetic rates of sun versus shade leaves of Hyptis emoryi Torr. Pl. Physiol. 58: 218-223.

- 1977. Internal leaf area and cellular $\mathrm{CO}_{2}$ resistance: photosynthetic implications of variations with growth conditions and plant species. Physiol. Plant. 40: $137-144$

- L. J. Zaragoza, AND W. K. Smith. 1975. Relation between mesophyll surface area, photosynthetic rate, and illumination level during development for leaves of Plectranthus parviflorus Henckel. Pl. Physiol. 55: 1067-1070.

Ostman, N. L., AND G. T. Weaver. 1982. Autumnal nutrient transfers by retranslocation, leaching, and litter fall in a chestnut oak forest in southern Illinois. Can. J. Forest Res. 12: 40-51.

Oxman, A. M., P. S. Goodman, ANd J. P. CoOper. 1977. The effects of nitrogen, phosphorus and potassium on rates of growth and photosynthesis of wheat. Photosynthetica 11: 66-75.

Pearce, R. B., G. E. Carlson, D. K. Barnes, R. H. Hart, AND C. H. Hanson. 1969. Specific leaf weight and photosynthesis in alfalfa. Crop Sci. 9: 423-426.

Ross, J. 1981. The radiation regime and architecture of plant stands. W. Junk, The Hague.

Schulze, E.-D., M. Fuchs, AND M. I. Fuchs. 1977. Spacial distribution of photosynthetic capacity and performance in a mountain spruce forest of northern Germany. III. The significance of the evergreen habit. Oecologia 30: 239-248.

SMITH, W. K., AND P. S. NoBel. 1978. Influence of irradiation, soil water potential, and leaf temperature on leaf morphology of a desert broadleaf, Encelia farinosa Gray (Compositae). Amer. J. Bot. 65: 429-432.

STEER, B. T. 1971. The dynamics of leaf growth and photosynthetic capacity in Capsicum frutescens $\mathrm{L}$. Ann. Bot. 35: 1003-1015.

van ElSACKER, P., AND I. IMPENS. 1984. Photosynthetic performance of poplar leaves at different levels in the canopy. In C. Sybesma [ed.], Advances in photosynthesis research, Vol IV, pp. 129-132.

YoshIDA, S., AND V. CORONEL. 1976. Nitrogen nutrition, leaf resistance, and photosynthetic rate of the rice plant. Soil Sci. Plant. Nutr. 22: 207-211. 